
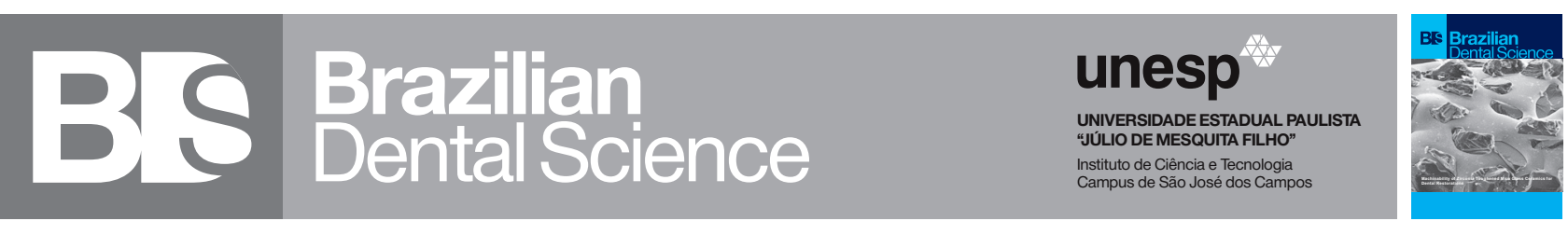

\title{
Generation I and Generation II Elastomeric Chains Characteristics Comparison in Artificial Saliva Immersion
}

Comparação das Características dos Elásticos Ortodônticos tipo Corrente de Geração I e Geração II em Imersão em Saliva Artificial

Marisa Icha Aisya SUBROTO ${ }^{1}$, Anindita Permata Hardarini PUTRI ${ }^{1}$, Leliana Sandra Devi Ade PUTRI ${ }^{2}$, Lusi HIDAYATI ${ }^{3}$

1 - Faculty of Dentistry, University of Jember, Jember, Indonesia.

2 - Department of Ortodontic, Faculty of Dentistry, University of Jember, Jember, Indonesia.

3 - Department of Dental Materials, Faculty of Dentistry, University of Jember, Jember, Indonesia.

\section{ABSTRACT}

Objective: To determine the force decay and discoloration in Generation I and Generation II elastomeric chain on artificial saliva immersion. Material and methods: Generation I and Generation II elastomeric chains stretched on an acrylic board and immersed in artificial saliva for $1,7,14,21$, and 28 days according to the group of days. On each specified day, the force of each sample measured by an orthodontic force gauge and the magnitude of the force obtained is entered to the formula to find out the force decay in percentage, whereas discoloration of each sample analyzed by the color reader with CIE Lab analysis. Results: The force decay between Generation I and Generation II elastomeric chains showed a statistically significant difference in every group of days, in which Generation II is more effective in maintaining stretch force. Similar to force decay, the discoloration in Generation I elastomeric chains on the 14th day showed significant value and Generation II elastomeric chains were more stable in maintaining color compared to Generation I. Conclusions: over the entire research period time, Generation II elastomeric chains are more stable in maintaining stretch forces and color compared to Generation I elastomeric chains.

\section{KEYWORDS}

Discoloration; Elastomeric chain; Force decay; Generation I; Generation II.

\section{RESUMO}

Objetivo: Determinar a queda de força e descoloração nos elásticos ortodônticos tipo corrente de Geração I e Geração II na imersão em saliva artificial. Material e métodos: Elásticos Geração I e Geração II foram esticados em placas de acrílico e imersas em saliva artificial por 1, 7, 14, 21 e 28 dias, de acordo com o grupo de dias. Em cada dia especificado, a força de cada amostra medida por um medidor de força ortodôntica e a magnitude da força obtida são inseridos na fórmula para descobrir sua queda em porcentagem, enquanto a descoloração de cada amostra foi analisada pelo leitor de cores "CIE Lab". Resultados: A queda da força entre os elásticos Geração I e Geração II apresentou diferença estatisticamente significativa em todos os grupos de dias, sendo que a de Geração II foi mais efetiva na manutenção da força de alongamento. Semelhante à queda de força, a descoloração nos elásticos da Geração I mostrou um valor significativo no $14^{\circ}$ dia, e elásticos da Geração II foram mais estáveis na manutenção da cor em comparação com a Geração I. Conclusões: durante todo o período de pesquisa, os elásticos tipo corrente da Geração II foram mais estáveis na manutenção das forças de alongamento e da cor em comparação com os elásticos da Geração I

\section{PALAVRAS-CHAVE}

Descoloração; Elástico corrente; Queda de força; Geração I; Geração II. 


\section{INTRODUCTION}

$\mathrm{E}$ lastomeric chains are one of the most used components in fixed orthodontic treatment. This kind of elastics available in the form of long chains with interconnected holes and when applied resemble ribbons that connect between teeth [1]. The use of elastomeric chains is a popular method of space closure because it has several advantages, such as its ease of application, relatively low cost, and a high level of comfort between patients and dentists [2].

Nevertheless, elastomeric chains also have disadvantages such as that are sufficiently sensitive to the oral environment, especially when exposed to saliva. Elastomeric chains are hydrophilic so that interaction between it and saliva will deform the internal bonds and make the physical properties become permanently deformed. This irreversible elastic deformation generates a force decay and discoloration of the elastomeric chains [3]. Also, factors in the oral cavity such as mastication pressure, tooth movement, $\mathrm{pH}$ variation, enzymes, and temperature of the oral cavity influence the degree of decrease in chain strength [4].

In previous studies, the greatest force decay of the elastomeric chains occurred in the first 24 hours ranging from $50 \%$ to $75 \%$ [5]. The stretching force on the elastomeric chain then experiences a constant gradual degradation and ultimately $60 \%$ of the initial force left after the use of elastomeric chains for 4 weeks [6]. Related to force decay, elastomeric chain discoloration is also a major problem for patients and dentists because it affects aesthetic appearance, intensify the frequency of visits, and increase financing costs.

The disadvantages of the elastomeric chain properties can be controlled by modifying the constituent chains of the polymer so that it becomes more stable and stronger, so that elastic deformation is not expected to occur easily. Recently, elastomeric chain modification is mostly done by changing its composition to minimize the shortcomings of its constituent structure, polyurethane [7].

One of the elastomeric chain renewal products is Generation I and Generation II produced by $\mathrm{Ormco}^{\circledR}$, USA. Generation II is an update of Generation I which is claimed for having a longer stretch strength and color stability, so it is expected to increase the effectiveness of treatment time [8]. Both products from Ormco $₫$ are still produced and used despite there is a claim that Generation II is more stable in maintaining force and color so that force decay and discoloration should be lower than Generation I.

Based on the description above, this study aims to determine the comparison of Generation I and Generation II elastomeric chain force decay and discoloration immersed in artificial saliva.

\section{MATERIAL AND METHODS}

This type of research is an experimental laboratory with a post-test only control group design, research model. This research was conducted at the Laboratory of Chemistry at the Faculty of Pharmacy, the University of Jember for immersion and measurement of force on samples and was carried out at the Material Characterization Laboratory of Materials and Metallurgical Techniques at the November 10 Institute of Technology to identify the sample structure. The study was conducted in December 2019.

The research sample used is the elastomeric chain produced by Ormco, USA Generation I and Generation II closed chain types with gray color variation with a sample size of 5 lumens. A total of 80 samples, each consisting of 40 samples from Generation I and 40 samples from Generation II then formed groups again based on group days, namely days $1,7,14,21$, and 28. Five groups of days formed from each Generation I and Generation II groups each consist of 4 elastomeric chains stretched on an acrylic board. (Figure 1) 
The prefix research was carried out to identify the building structure of each sample group using the Fourier Transform Infra-red (FTIR) tool. The way the FTIR works is by firing an infrared beam which will then produce a reading in the form of a spectrum. From this spectrum, the constituent functional groups of each sample will be identified and then compared as supporting data to conclude the effect of the building structure on the physical properties of the two elastomeric chain groups.

Determination of the elastomeric chain stretch length is done by pulling the elastomeric chain using an orthodontic force gauge until it reaches a force of 200 grams. The optimal force in canine retraction with the point of retraction in the canines and molars is 200 grams [9].

When reaching a force of 200 grams then the elastomeric chain is measured in length and the result obtained is the length used in stretching on the acrylic board and becomes the benchmark for the length of the force gauge withdrawal when measuring the force on days $1,7,14,21$ and 28. Based on the results the elastomeric chain lengths of Generation I and Generation II when stretched with 200 grams force showed $18 \mathrm{~mm}$.

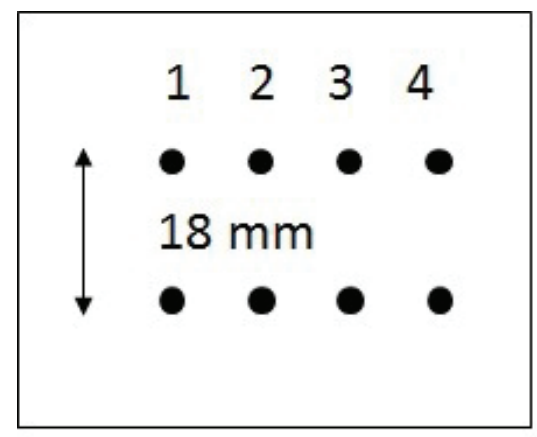

$40 \mathrm{~mm}$

\section{$60 \mathrm{~mm}$}

Figure 1 - Illustration of acrylic board. Source - Personal Illustration.

The study was carried out by stretching all the samples on the acrylic board according to the generation group and the day group, then immersed in artificial saliva with a $\mathrm{pH}$ of 7 and during immersion was kept in an incubator to adjust the temperature of the oral cavity at 37 ${ }^{\circ} \mathrm{C}$. Then on every day that is determined the 1st, 7th, 14th, 21st, and 28th the measurement of the force on that day uses an orthodontic force gauge and force shown on force gauge is calculated with the formula to find out the decrease in the stretching force in the form percentages and color changes were measured using a color reader (Konica Minolta, Japan) with CIE Lab color analysis. (Figure 2). The formula used to determine force decay are:

Force decay percentage: $\frac{A-B}{B} \times 100 \%$

Information:

$A=$ initial force (200 grams)

$\mathrm{B}=$ magnitude of force at each measurement time (days 1, 7, 14, 21 and 28)

Data from the results of force decay that has been obtained is then performed a normality test using the Shapiro-Wilk test because the sample number is less than 50 and the homogeneity test uses the Levene test. Then a different test is done using the Kruskal-Wallis test and further tests with the Mann-Whitney test. Statistical analysis was performed with IBM SPSS Statistics for Windows, Version 20.0. Armonk, NY: IBM Corp. While the formula to determine the color change is to use the CIE Lab color analysis as follows:

$$
\Delta E=\left[\left(\Delta \mathrm{L}^{*}\right)^{2}+\left(\Delta \mathrm{a}^{*}\right)^{2}+\left(\Delta \mathrm{b}^{*}\right)^{2}\right]^{1 / 2}
$$

Information:

$$
\Delta \mathrm{E}=\text { total color difference }
$$

$\Delta \mathrm{L} *=(\mathrm{L} *$ sample minus $\mathrm{L} *$ standard $)=$ difference in light and dark $(+=$ brighter, $-=$ dark)

$\Delta \mathrm{a} *=(\mathrm{a} *$ sample minus a $*$ standard $)=$ red and green difference $(+=$ red, $-=$ green $)$

$\Delta \mathrm{b} *=(\mathrm{b} *$ sample minus $\mathrm{b} *$ standard $)=$ yellow and blue difference $(+=$ more yellow, = blue) 


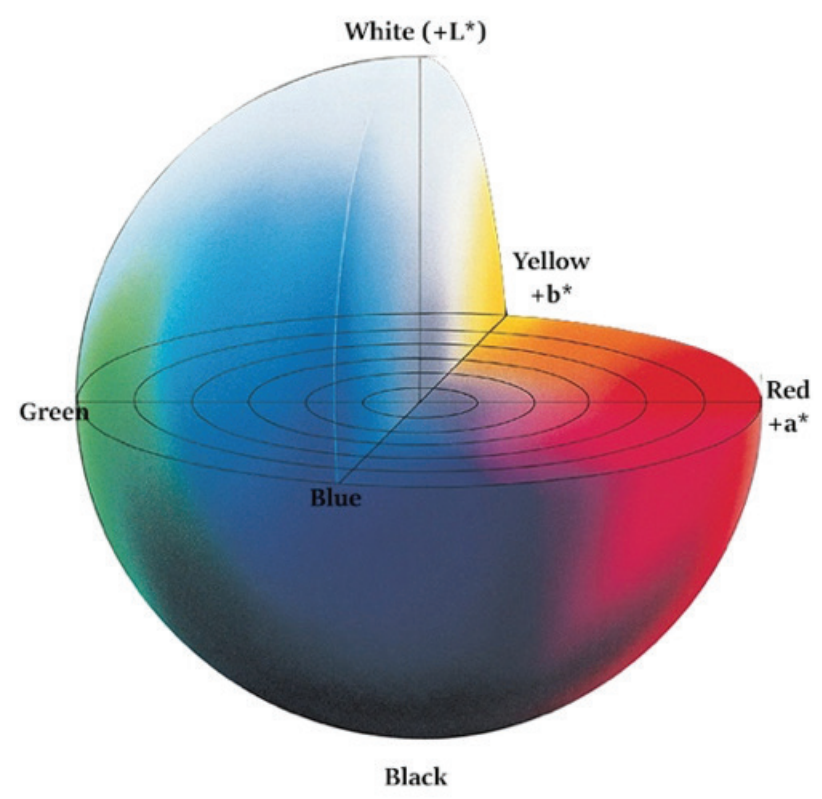

Figure 2 - Colour dimensions in CIELAB.

Source - https://sensing.konicaminolta.asia/what-is-cie-1976-labcolor-space/

Data on the results of color changes that have been obtained are then performed a normality test using the Shapiro-Wilk test and a homogeneity test using the Levene test. Then a different test is done using the One-way ANOVA test and further tests with Tukey. Statistical analysis was performed with IBM SPSS Statistics for Windows, Version 20.0. Armonk, NY: IBM Corp.

\section{RESULTS}

\section{Force decay}

Generally, all samples experienced elastic deformation in the form of loss of elasticity and physical changes marked by elastomeric chain lengthening from their original size. Samples from Generation I and Generation II both have a gradual decrease in stretching force. The force decay of Generation I elastomeric chains are listed in the following tables I and II:
Table I - Force decay of Generation I elastomeric chains

\begin{tabular}{|c|c|c|c|c|c|}
\hline \multirow{2}{*}{ Day } & \multicolumn{4}{|c|}{ Force Decay Generasil } & \multirow{2}{*}{ Mean } \\
\hline & Sample1 & Sample 2 & Sample 3 & Sample 4 & \\
\hline 1 & $22,04 \%$ & $14,95 \%$ & $5,03 \%$ & $17,79 \%$ & $14,95 \%$ \\
\hline 7 & $26,29 \%$ & $14,95 \%$ & $17,79 \%$ & $26,29 \%$ & $21,33 \%$ \\
\hline 14 & $50,39 \%$ & $50,39 \%$ & $43,30 \%$ & $43,30 \%$ & $46,84 \%$ \\
\hline 21 & $64,56 \%$ & $57,48 \%$ & $50,39 \%$ & $50,39 \%$ & $55,70 \%$ \\
\hline 28 & $64,56 \%$ & $64,56 \%$ & $50,39 \%$ & $50,39 \%$ & $57,48 \%$ \\
\hline
\end{tabular}

Source - Personal Documentation

Table II - Force decay of Generation II elastomeric chains

\begin{tabular}{|c|c|c|c|c|c|}
\hline \multirow{2}{*}{ Day } & \multicolumn{4}{|c|}{ Force Decay Generasi II } & \multirow{2}{*}{ Mean } \\
\hline & Sample1 & Sample2 & Sample 3 & Sample 4 & \\
\hline 1 & $2,19 \%$ & $0,77 \%$ & $7,86 \%$ & $7,86 \%$ & $4,67 \%$ \\
\hline 7 & $12,12 \%$ & $12,12 \%$ & $14,95 \%$ & $13,53 \%$ & $13,18 \%$ \\
\hline 14 & $14,95 \%$ & $13,53 \%$ & $16,37 \%$ & $17,79 \%$ & $15,66 \%$ \\
\hline 21 & $22,04 \%$ & $29,13 \%$ & $22,04 \%$ & $29,13 \%$ & $25,58 \%$ \\
\hline 28 & $22,04 \%$ & $22,04 \%$ & $29,13 \%$ & $36,21 \%$ & $27,35 \%$ \\
\hline
\end{tabular}

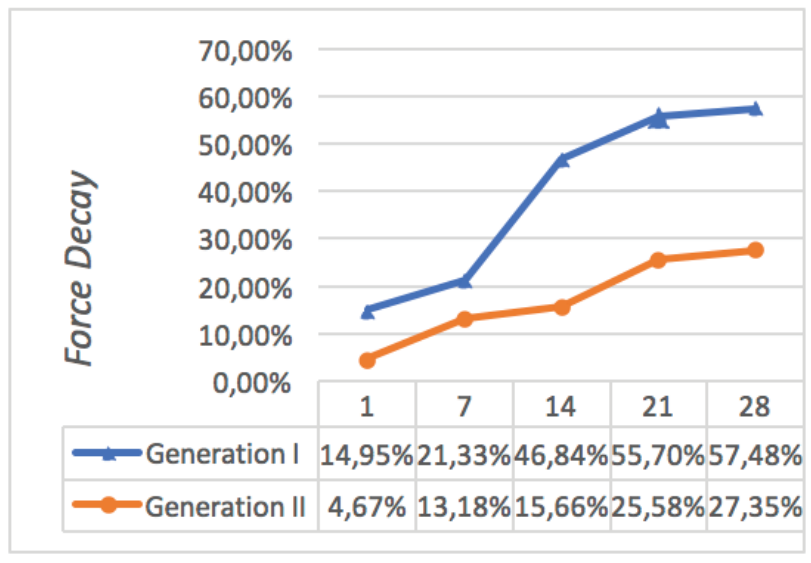

Figure 3 - Force decay comparison graph of Generation I and Generation II elastomeric chains.

Source - Personal Documentation.

In the graph showing the comparison of force decay between Generation I and Generation II (Figure 3), it appears that Generation II percentage of force decay every day $1,7,14,21$, and 28 is always lower than Generation I. The lower value of the percentage of force decay, the less an elastomeric chain experiences a force decay. Until the 28th day or the fourth week, 
Generation II only experienced a force decay by $27.35 \%$ which is the range of force decay in Generation I when it was still on the 7th day.

The results of the study then analyzed statistically. Based on the results of the normality and homogeneity test, the significance of the data showed abnormal and non-homogeneous data variations, so that the different tests are performed using the Kruskal-Wallis test nonparametric test. Kruskal-Wallis test results show a significance value of $0.000<0.05$ which means there are significant differences in all groups of days from Generation I and Generation II. Then proceed with the Mann-Whitney test. The test results show that there are significant differences in Generation I between 7th and 14th days while in Generation II there are significant differences between 1st and 7th days and 14th and 21st days. Further tests are also conducted between generations which show the results that there is a significant difference between Generation I and Generation II on the 7th, 14th, 21st, and 28th days.

\section{Discoloration}

Samples from Generation I and Generation II both have gradual color changes. The number of color changes for Generation I and Generation II are listed in the following tables (III and IV) by way of interpretation:

$$
\begin{aligned}
& \Delta \mathrm{E}=\text { total color difference } \\
& \Delta \mathrm{L} *=(\mathrm{L} * \text { sample minus } \mathrm{L} * \text { standard })=
\end{aligned}
$$
difference in light and dark $(+=$ brighter, $-=$ dark)

$\Delta \mathrm{a} *=(\mathrm{a} *$ sample minus a $*$ standard $)=$ red and green difference $(+=$ red, $-=$ green $)$

$\Delta \mathrm{b} *=(\mathrm{b} *$ sample minus $\mathrm{b} *$ standard $)=$ yellow and blue difference $(+=$ more yellow, $=$ blue)

\begin{tabular}{|c|c|c|c|c|c|}
\hline $\begin{array}{l}\text { Group/ } \\
\text { Period }\end{array}$ & $\begin{array}{l}\text { Sample } \\
\text { Code }\end{array}$ & $(\Delta \mathrm{L})^{2}$ & $(\Delta \mathbf{a})^{2}$ & $(\Delta \mathbf{b})^{2}$ & $\Delta \mathbf{E}$ \\
\hline \multirow{4}{*}{ gen I/1days } & 1 & 0,0382 & 0,0187 & 0,0282 & 0,2916 \\
\hline & 2 & 0,0024 & 0,0750 & 0,0061 & 0,2889 \\
\hline & 3 & 0,1169 & 0,0750 & 0,0080 & 0,4470 \\
\hline & 4 & 0,0095 & 1,1995 & 0,0245 & 1,1107 \\
\hline \multirow{4}{*}{ gen $1 / 7$ days } & 1 & 0,2356 & 0,5878 & 0,0238 & 0,9204 \\
\hline & 2 & 0,9422 & 3,2001 & 0,0485 & 2,0472 \\
\hline & 3 & 0,1154 & 0,0000 & 0,0078 & 0,3510 \\
\hline & 4 & 0,2356 & 0,2612 & 0,0393 & 0,7322 \\
\hline \multirow{4}{*}{$\begin{array}{c}\text { gen } \mathrm{l} / 14 \\
\text { days }\end{array}$} & 1 & 0,0024 & 1,1995 & 0,0178 & 1,1044 \\
\hline & 2 & 2,4121 & 0,1687 & 0,0045 & 1,6079 \\
\hline & 3 & 0,1154 & 5,4167 & 0,0209 & 2,3565 \\
\hline & 4 & 0,0848 & 0,0187 & 0,0011 & 0,3235 \\
\hline \multirow{4}{*}{$\begin{array}{c}\text { gen } 1 / 21 \\
\text { days }\end{array}$} & 1 & 0,0476 & 1,3225 & 0,1139 & 1,2182 \\
\hline & 2 & 0,0587 & 0,0163 & 0,2173 & 0,5407 \\
\hline & 3 & 1,5270 & 0,0367 & 0,0661 & 1,2767 \\
\hline & 4 & 0,7608 & 1,3225 & 0,0285 & 1,4532 \\
\hline \multirow{4}{*}{$\begin{array}{c}\text { gen } 1 / 28 \\
\text { days }\end{array}$} & 1 & 0,0024 & 0,0000 & 0,0147 & 0,1307 \\
\hline & 2 & 0,0861 & 0,9184 & 0,2567 & 1,1231 \\
\hline & 3 & 0,0096 & 1,1995 & 0,0008 & 1,0999 \\
\hline & 4 & 0,0383 & 2,2679 & 0,0001 & 1,5186 \\
\hline
\end{tabular}

Table III - Discoloration value in Generation I elastomeric chains

Source - Personal Documentation

\begin{tabular}{|c|c|c|c|c|c|}
\hline $\begin{array}{l}\text { Group/ } \\
\text { Period }\end{array}$ & $\begin{array}{c}\text { Sample } \\
\text { Code }\end{array}$ & $(\Delta \mathrm{L})^{2}$ & $(\Delta \mathbf{a})^{2}$ & $(\Delta \mathbf{b})^{2}$ & $\Delta \mathbf{E}$ \\
\hline \multirow{4}{*}{ gen II/1 days } & 1 & 0,0382 & 0,0187 & 0,0282 & 0,2916 \\
\hline & 2 & 0,0024 & 0,0750 & 0,0061 & 0,2889 \\
\hline & 3 & 0,1169 & 0,0750 & 0,0080 & 0,4470 \\
\hline & 4 & 0,0095 & 1,1995 & 0,0245 & 1,107 \\
\hline \multirow{4}{*}{$\begin{array}{c}\text { gen II/7 } \\
\text { days }\end{array}$} & 1 & 0,7632 & 0,1469 & 0,0078 & 0,9581 \\
\hline & 2 & 0,7632 & 0,1469 & 0,0078 & 0,9581 \\
\hline & 3 & 0,7632 & 0,8000 & 0,0030 & 1,2515 \\
\hline & 4 & 0,1154 & 0,2612 & 0,0011 & 0,6146 \\
\hline \multirow{4}{*}{$\begin{array}{c}\text { gen } \| / 14 \\
\text { days }\end{array}$} & 1 & 0,7632 & 0,1469 & 0,0078 & 0,9581 \\
\hline & 2 & 0,7632 & 0,1469 & 0,0078 & 0,9581 \\
\hline & 3 & 0,7632 & 0,8000 & 0,0030 & 1,2515 \\
\hline & 4 & 0,1154 & 0,2612 & 0,0011 & 0,6146 \\
\hline \multirow{4}{*}{$\begin{array}{c}\text { gen } \| / 21 \\
\text { days }\end{array}$} & 1 & 0,7632 & 0,1469 & 0,0078 & 0,9581 \\
\hline & 2 & 0,7632 & 0,1469 & 0,0078 & 0,9581 \\
\hline & 3 & 0,7632 & 0,8000 & 0,0030 & 1,2515 \\
\hline & 4 & 0,1154 & 0,2612 & 0,0011 & 0,6146 \\
\hline \multirow{4}{*}{$\begin{array}{c}\text { gen } 11 / 28 \\
\text { days }\end{array}$} & 1 & 0,7632 & 0,1469 & 0,0078 & 0,9581 \\
\hline & 2 & 0,7632 & 0,1469 & 0,0078 & 0,9581 \\
\hline & 3 & 0,7632 & 0,8000 & 0,0030 & 1,2515 \\
\hline & & 0,1154 & 0,2612 & 0,0011 & 0,6146 \\
\hline
\end{tabular}

Table IV - Discoloration value in Generation II elastomeric chains

Source - Personal Documentation 
The value of $\Delta \mathrm{E}$ Generation II on every day $1,7,14,21$, and 28 is always lower than Generation I. The lower the value of $\Delta \mathrm{E}$, then an elastomeric chain experiences fewer color changes. Although both experiences a discoloration, Generation II is relatively more stable in maintaining color that is marked by a small and constant change in value until the 28th day while Generation I has a very significant color change on the 14th day.

Data on the results then analyzed statistically. Based on the results of the normality and homogeneity test, the significance of the data shown normal and homogeneous data variations. The One Way Anova test was then performed, and it was found that the significant value in each group showed a value of $p=$ $0.012(\mathrm{p}<0.05)$ for Generation $\mathrm{I}$ and $\mathrm{p}=$ 0.395 ( $p>0.05$ ) for Generation II. Generation I elastomeric chains have different means so it can be concluded that the average Generation I is significantly different and Generation II has the same average so it can be concluded that the average Generation II elastomeric chain is not significantly different. The results of the Tukey follow-up test, Generation I with an immersing time of 14 days showed a value of $p=0.027$ ( $p$ $<0.05)$ so that it could be concluded that there were significant differences. Whereas in the elastomeric chain Generation I with immersion time 1, 7, 21, and 28 days there were no significant differences. Whereas in Generation II there were no significant differences in all-time groups. In Tukey tests, there was a significant difference between the 7-day and 14-day immersion times with $\mathrm{p}=0.03(\mathrm{p}<0.05)$ and $\mathrm{p}$ $=0.01(\mathrm{p}<0.05)$. Whereas for the duration of immersion of 1 day, 21 days and 28 days, there were no significant differences due to $\mathrm{p}>0.05$.

\section{Fourier Transform Infra-red (FTIR)}

The identification of the elastomeric chain structure of the two groups, Generation I and Generation II, was carried out using the FTIR instrument whose spectrum as an output to interpret. The spectrum of Generation I and
Generation II shows a similar pattern, this shows that the structure of Generation I and Generation II elastomeric chains are mostly the same (Figure 4).

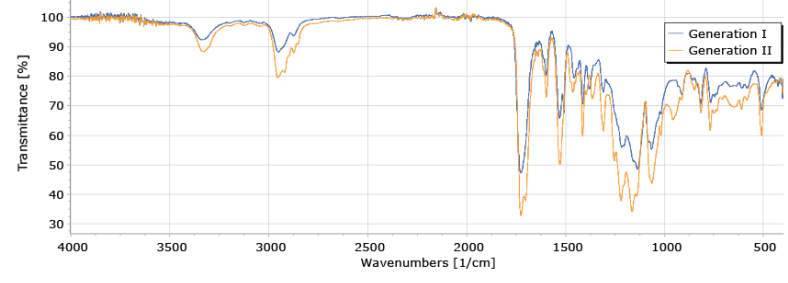

Figure 4 - Superimposed FTIR spectrum of Generation I and Generation II elastomeric chain.

Source - Personal Documentation associated Material and Metallurgical Engineering Department Sepuluh November Institute of Technology, Indonesia.

Each spectrum has 2 parts that become a hint in analyzing the structure of the sample, wavenumber on the $\mathrm{x}$-axis and transmittance on the $y$-axis. The numbers of wavenumber of the lowest point in a spectrum (peaks) indicate the type of a functional group, while the percentage of transmittance indicates the number of functional groups (Table V).

Table V - Identified functional groups and transmittance of Generation I and Generation II elastomeric chains.

\begin{tabular}{|c|c|c|c|}
\hline \multirow{2}{*}{ No. } & \multirow{2}{*}{$\begin{array}{c}\text { Functional } \\
\text { Groups }\end{array}$} & \multicolumn{2}{|c|}{ Wavenumber (cm-1) / Transmittance (\%T) } \\
\hline & & Generation I & Generation II \\
\hline 1 & $0-\mathrm{H}$ & $3337,41 \mathrm{~cm}-1 / 92,272 \%$ & $3326,22 \mathrm{~cm}-1 / 88,256 \%$ \\
\hline 2 & $\mathrm{~N}-\mathrm{H}$ & $2951,14 \mathrm{~cm}-1 / 88,217 \%$ & $2953,17 \mathrm{~cm}-1 / 79,633 \%$ \\
\hline 3 & $\mathrm{C}=0$ & $1727,39 \mathrm{~cm}-1 / 47,306 \%$ & $1725,38 \mathrm{~cm}-1 / 32,873 \%$ \\
\hline 4 & $\mathrm{C}=\mathrm{C}$ & $1596,93 \mathrm{~cm}-1 / 80,230 \%$ & $1596,29 \mathrm{~cm}-1 / 72,890 \%$ \\
\hline 5 & $0-\mathrm{H}$ & $1413,38 \mathrm{~cm}-1 / 70,636 \%$ & $1413,48 \mathrm{~cm}-1 / 59,736 \%$ \\
\hline 6 & $\mathrm{C}-\mathrm{N}$ & $1309,54 \mathrm{~cm}-1 / 74,705 \%$ & $1309,23 \mathrm{~cm}-1 / 61,517 \%$ \\
\hline 7 & $\mathrm{C}-0$ & $1216,08 \mathrm{~cm}-1 / 56,031 \%$ & $1219,67 \mathrm{~cm}-1 / 37,873 \%$ \\
\hline 8 & $\mathrm{C}-0$ & $1136,16 \mathrm{~cm}-1 / 48,625 \%$ & $1163,43 \mathrm{~cm}-1 / 34,179 \%$ \\
\hline 9 & $\mathrm{C}-0$ & $1065,98 \mathrm{~cm}-1 / 55,319 \%$ & $1064,10 \mathrm{~cm}-1 / 43,909 \%$ \\
\hline 10 & $\mathrm{C}=\mathrm{C}$ & $816,82 \mathrm{~cm}-1 / 70,565 \%$ & $815,79 \mathrm{~cm}-1 / 67,771 \%$ \\
\hline
\end{tabular}

Source - Personal Documentation associated Material and Metallurgical Engineering Department Sepuluh November Institute of Technology, Indonesia.

The percentage of transmittance indicates how much light is not absorbed by a functional group. When the percentage of transmittance is low, less light passes through the group. 
Thus, the lower the value of the percentage of transmittance, the greater the content of a functional group in a sample. The results show that Generation II has a lower percentage of transmittance so it can be presumed there are more numbers of each functional group that compose Generation II than Generation I.

\section{DISCUSSION}

\section{Force Decay}

Elastomeric chains are made from polyurethane which is one type of synthetic rubber. Related to elastic materials in general, elastomeric chains can experience loss of elasticity which causes a force decay. A force decay on the elastics can occur by stretching over its elasticity limit. Based on Hooke's Law, when elastics stretched over its elasticity limit, a deformation will occur in the form of prolongation from its original size so that when stretched with the same length it will not give the same force as the initial force [10].

Based on many previous studies, the greatest force decay occurred in the first 24 hours ranging from $50-75 \%$ of the initial force [5]. Research on the two groups on Day 1 showed results that both Generation I and Generation II did not show a decrease in the force of up to $50 \%$. The Generation I group experienced a decrease in force by $14.95 \%$ and Generation II gave a better result which was only a force decrease of 4.67\%. This shows that both Generation I and Generation II have not decreased by as much as other elastomeric chain brands, and both are equally good at maintaining stretching forces in the first 24 hours.

On the 7th day, Generation I experienced a force decay of $21.33 \%$ while for Generation II the decrease in force occurred was $13.18 \%$. The force decay that occurs on the seventh day is due to the elastomeric chain starting to interact with saliva which causes interaction of water molecules in the saliva with the elastomeric chain molecules [11]. The character of the elastomeric chains that absorbs water causes hydrogen atoms to enter the polymer molecule because of the negative charge from the oxygen atoms in the polymer. When hydrogen ions and oxygen bind it will cause the elastomer to swell microscopically [12].

On the 14th day, there was a force decay of $46.84 \%$ in Generation I and $15.66 \%$ in Generation II. On the 14th day, there was a drastic change in force decay of Generation I from the previous day by $21.33 \%$ to 2 times which is $46.84 \%$. Generation II still gives better results than Generation I, with a difference almost twice over Generation II.

On the following day, the two groups showed results that did not differ greatly from the 21st day and 28th day. Generation I experienced a force decay of $55.70 \%$ and $57.48 \%$ while for Generation II experienced a force decay of $25.58 \%$ and $27.35 \%$. This is compatible with the theory that after a large decrease in stretching force on day 1 , the elastomeric chain subsequently experiences a slow and gradual decrease in stretching force almost constant until the third week onwards $[5,4]$.

Generation II since the first day to the 28th day experienced less force decay and more constant in maintaining force compared to Generation I, which in its graph had experienced a drastic increase on the 14th day. So if it is concluded from the theory that the decrease in the ideal elastomeric chain strength force is as minimal as possible and constant, Generation II is better than Generation I [13].

\section{Discoloration}

The process of changing the color of the elastomeric chain is dependent on the absorption of water into the polymer and is followed by the chemical degradation of the elastomeric chain [14]. The elastomeric chain can absorb small molecules such as water. The elastomeric chain will experience a decrease in intermolecular force between chains when absorbing water. In the process of absorption of water by the 
elastomeric chain, hydrogen ions from the water will enter the polymer molecules. The entry of hydrogen ions is due to the positive charge of oxygen atoms present in the polymer. Water molecules will enter between the polymers so that the elastomeric chain will expand. Water in the polymer will cause the distance between the polymer molecules to be far so that the polymer bonds become tenuous [15].

The CIE Lab color system used in this study is commonly used to assess small color changes. The advantage of this system for color measurement is that it more accurately represents human sensitivity to color.

When comparing the values of $\Delta \mathrm{L}, \Delta \mathrm{a}$, and $\Delta \mathrm{b}$, the result is that $\mathrm{L}$ of all elastomeric chains decreases after $1,7,14.21$, and 28 days. This is due to an increase in elastomeric chain opacity after exposure to the oral.

When stretched and exposed to the oral environment, the elastomeric chain absorbs water and saliva and the internal bonds break. A broken internal bond causes permanent deformation in the form of permanent and permanent staining [16].

Elastomeric chains are made with polyurethane synthesis produced with various chemicals. Chemical changes affect the configuration of the elastomeric chain and its ability to be deformed by external agents. Processing conditions can also affect the structure and configuration of the polymer chain. In addition, surface characteristics, such as texture and porosity, may differ between manufacturers and are influenced by external agents [5].

Based on the color analysis that has been done, the results show that there are significant differences in the color degradation that occurs between the control and treatment groups. The subsequent color degradation is categorized according to the value of the change using the NBS rating system based on Table VI.
Table VI - National Bureau of Standards (NBS) rating system.

\begin{tabular}{|c|c|}
\hline NBS Units & $\begin{array}{c}\text { Critical remarks on color differ- } \\
\text { ence }\end{array}$ \\
\hline $0.0-0.5$ & $\begin{array}{c}\text { Extremely slight change } \\
0.6-1.5\end{array}$ \\
\hline $1.6-3.0$ & Slight change \\
$3.1-6.0$ & Perceiveable change \\
\hline $6.1-12.0$ & Marked change \\
more than 12.0 & Extremely marked change \\
\hline
\end{tabular}

Source - The National Bureau of Standards (NBS), United States.

The value of color change on in vitro studies is clinically acceptable if $\Delta \mathrm{E} \leq 3.70$, whereas on in vivo studies the color change is acceptable if $\Delta \mathrm{E} \leq 6.80$. This research is an in vitro study with the biggest color change $\leq 3.70$ so it is still acceptable.

Generation II stability at maintaining force and color also supported by the comparison test of its constituent structures. Generation II has the same constituent functional groups as Generation I, but the transmittance of each functional group is always lower. The transmittance value in a spectrum shows the amount of light that is not absorbed by a compound in the polymer when carried out the FTIR test. The lower the percentage transmittance value, the more light is absorbed by compounds in a polymer. This high absorption of light indicates that the functional groups making up a specimen are less. Because all Generation II functional groups have lower transmittance percentage values than Generation I, it can be concluded that Generation II is composed of more functional groups than Generation I, especially in hydroxyl $(\mathrm{OH})$ and isocyanate groups $(\mathrm{N}=\mathrm{C}=\mathrm{O})$ which forms polyurethane [17].

The character of polyurethanes which are constituents of elastomeric chains depends on the number of crosslinks in the polymer. The crosslinks determined from the ratio of hydroxyl groups and isocyanate groups $(\mathrm{OH} /$ NCO). A high number of crosslinks also support the character of the elastomeric chain which is 
always in contact with saliva because the more crosslink contained, the more difficult the water enters the elastomeric chain and binds to the polymer. So that swelling in the polymer will be less and the elastomeric chain will be more stable in maintaining force and color [18].

\section{CONCLUSION}

Under the circumstances of this study, the following conclusions were suggested:

1. Generation I elastomeric chains experienced a significant decrease in stretching force between days 7 and 14 whereas Generation II elastomeric chains experienced a significant decrease in stretching force between days 1 and 7 and days 14 and 21;

2. Changes in color in Generation I elastomeric chains on Day 14 show significant value;

3. During the research time, Generation II Elastomeric chains are more stable in maintaining color and stretching force compared to Generation I.

\section{Conflict of interest}

The authors have no proprietary, financial, or other personal interest of any nature or kind in any product, service, and/or company that is presented in this article.

\section{Acknowledgement}

none.

\section{REFERENCES}

1. Bhalaji SI. Orthodontics: the artand science.3rd Edition. New Delhi: Arya;2004.

2. Bousquet JA Jr, Tuesta 0, Flores-Mir C. In vivo comparison of force decay between injection molded and die-cut stamped elastomers. Am J Orthod Dentofacial Orthop. 2006;129(3):384-9. doi:10.1016/.jajodo.2005.09.002
3. Cavalcante JS, de Castelluccie Barbosa M, Sobral MC. Evaluation of the susceptibility to pigmentation of orthodontic esthetic elastomeric ligatures. Dental Press J Orthod.2013;18(2):20.e1-20.e208. doi:10.1590/s217694512013000200008

4. Weissheimer A, Locks A, de Menezes LM, Borgatto AF,Derech CD. In vitro evaluation of force degradation of elastomeric chains used in orthodontics. Dental Press J Orthod. 2013;18(1):55-62. doi:10.1590/s2176-94512013000100014

5. Da Silva DL Force degradation in orthodontic elactics chains. Rev Odonto cienc 2009;24(3):274-8.

6. Prastiti VP.Perbandingan kekuatan elastomeric chains bahan thermoplastic dan thermoset [tesis]. Surabaya: Fakultas Kedokteran Gigi; 2018.

7. Sulaiman $T H$, Eriwati $Y K$, Indrani DJ.Pengaruh suhu terhadap penurunan gaya regang power chain ortodontik dalam larutan saliva buatan. Depok: Fakultas Kedokteran Gigi Universitas Indonesia; 2014.

8. Ormco. ProductCatalog. California: Ormco Corporation;2017.

9. Talwar A. Comparative evaluation of Nickel-Titanium closed coil spring and elastomeric chain for canine retraction. New Delhi: Department of Orthodontics and Dentofacial Orthopaedics;2018.

10. Doyan A, Taufik M, Anjani R. Pengaruh pendekatan multi representasi terhadap hasil belajar fisika ditinjau dari motivasi belajar peserta didik. Jurnal Penelitian Pendidikan IPA (JPPIPA) 2018;4(1):38-9. doi: 10.29303/jppipa.v4i1.99

11. Baty DL, Storie DJ, von Fraunhofer JA. Synthetic elastomeric chains: a literature review. Am J Orthod Dentofacial Orthop. 1994;105(6):536-542. doi:10.1016/S0889-5406(94)70137-7

12. Brantley WA, Eliades, T.Ortodontics materials: scientific and clinical aspects. New York:mThieme;2001.

13. Halimi A,Benyahia H,Doukkali A, Azeroual MF,Zaoui F.A systematic review of force decay in orthodontic elastomeric power chains. Int Orthod 2012;10(3):223-40. doi:10.1016/.ortho.2012.06.013

14. Kadhum S, Alhuwaizi,AF.Assessment of the color stability of clear elastomeric ligatures: in vivo study.J Baghdad College of Dent 2017;29(3):128-34. doi: https://doi.org/10.12816/0041192

15. Suprayugo M, Eriwati YK, Santosa AS. Effect of pH of soft drinks on force decay in orthodontic power chains. J Physics: Conference Series 2018;1073(6). doi: https://doi.org/10.1088/17426596/1073/6/062016

16. Alif J, Yudianto A. Pengaruh lama paparan pengikat cincin elastomer ortodonti terhadap kualitas dna the effect of long exposure binder rings. Jurnal Biosains Pascasarjana 2017;19(1). doi:101088/17426596/1073/6/062016

17. Trovati G, Sanches EA, Neto SC, Mascarenhas YP,Chierice GO. Characterization of polyurethane resins by FTIR, TGA, and XRD. J Appl Polymer Sci 2009;115:263-8 doi:10.1002/app.31096

18. Sonip A, Aprilina E, Anita L, Sagala B, Risanti M, Kurniati M. Analisis ikatan molekul protein (Gugus Fungsi C-N) pada miselium jamur tiram dengan metode fourier transform infra-(FTIR). Prosiding Seminar Nasional Fisikap(EJournal) SNF 2015:4:2339
Marisa Icha Aisya Subroto

(Corresponding address)

Jalan Kalimantan No. 37, Kampus Tegalboto, Jember, Jawa Timur, 68121, Indonesia.
Date submitted: 2020 Apr 28

Accept submission: 2020 Jul 15 